\title{
The City as an Onion? Case Studies of Electoral Geography in Prague and Warsaw ${ }^{1}$
}

\author{
Daniel Kerekes ${ }^{2}$ \\ Department of Political Science, Masaryk University, Brno
}

\begin{abstract}
The City as an Onion? Case Studies of Electoral Geography in Prague and Warsaw. Electoral geographical research into urban territories shows a distinction in voting behaviour between a city centre and its surroundings. A recent exploratory study of the electoral geography of Prague found that distance from the city centre was the variable that best explained the spatial variation of votes, which might follow a concentric pattern and, thus, it recommended seeking a theoretical explanation in urban sociology, e.g. in the Burgess model of the city. Following this recommendation, I compared spatial patterns of voting behaviour in two cities - Warsaw and Prague. Using component analysis, I reduced the number of analysed variables to one for each city representing the main spatial polarisation. In Prague, voting behaviour showed a distinction between the city centre, inner suburbs and outer suburbs. While the city centre and the outer suburbs were conservative, the inner suburbs tended to vote for the left. This partially follows the Burgess model. On the other hand, the electoral geography of Warsaw showed a different structure. In this article I present a way of visualising urban electoral data in maps that avoid distortion caused by varying polygon size.

Sociológia 2020, Vol. 52 (No. 3: 245-272)

https://doi.org/10.31577/sociologia.2020.52.3.11
\end{abstract}

Key words: Burgess model; urban electoral geography; Prague; Warsaw; urban sociology; voting behaviour

\section{Introduction}

Electoral geography - specifically, the area of vote studies, which explains the spatial variation of electoral behaviour (Leib - Quinton 2011) - usually focuses on a whole election arena (meaning a country) or on specific regions. It is rare that the researched case is as small as a city. The gap is - I think - caused by the lack of good data. There are two aspects to the problem. In some countries, votes are counted at higher levels of election administration than a polling station. Therefore, election statistics at the finest possible level of fragmentation, which the secrecy of voting allows, is absent. The other aspect is whether it is possible to assign locations to ward data. That is essential for electoral geography.

Big cities are economically, socially and politically highly heterogeneous on the inside. Electoral polarisation and the spatial variation of electoral behaviour

\footnotetext{
1 Hereby I would like to thank my supervisor Roman Chytilek, associate professor at Department of Political Science, Masaryk University, and professor Tomasz Zarycki, director of Institute for Social Studies, University of Warsaw, for sharing their insights and advices as well as to Paulina Szczepan for enormous help with data processing.

This publication was written at Masaryk University with the support of the Specific University Research Grant provided by the Ministry of Education, Youth and Sports of the Czech Republic.

2 Address: Ing. Mgr. Daniel Kerekes, Ph.D., Department of Political Science, Faculty of Social Studies, Joštova 10, 60200 Brno, Czech Republic. E-mail: kerekes@mail.muni.cz
} 
in a big city might be similar or even more marked than polarisation at the national level. Nevertheless, electoral geography often sees a city as one homogeneous statistical unit with aggregated data or, in better cases, as several units of territorial-administrative division. Thus, much of the spatial variation is lost along with information about urban voting patterns. Such electoral geography analyses give more insight into the spatial patterns of the electoral behaviour of rural, rather than urban, voters.

However, data availability, automation and the development of geographic information systems provide us with the opportunity to look at the spatial aspects of electoral behaviour even at a lower level of data aggregation. Analysing a city in terms of the spatial distribution of votes is not only academically, but also socially, relevant and beneficial. As O'Loughlin et al. (1997) and Charney - Malkinson (2015) noted, urban spatial electoral data can often substitute for lacking or expensive spatial sociological data. The general public is provided with alternative information on the socio-economic, ethnic, linguistic and religious spatial structure of the city's inhabitants. Compared to data from censuses, it is more up-to-date because of the greater frequency of elections; and, of course, more cost-effective than questionnaire surveying.

There is no standardised and unified methodological or theoretical approach to researching a city's spatial electoral patterns. Authors of review articles who sought to distinguish the sub-disciplines of electoral geography (Archer Shelley 1985; Flint - Taylor 2007; Leib - Quinton 2011; Reynolds 1990) have not even recognised the urban electoral geography as a sub-discipline of electoral geography.

The stimulus for writing this article was provided by an explanatory study of spatial voting patterns in the city of Prague (Kerekes 2018a). The most recent first-order elections (to the Chamber of Deputies, the lower chamber of the Czech Parliament) were spatially explored using dozens of available geographic, socioeconomic and demographic variables, and variables characterising the various components of the quality of life. The study shows that the strongest explanatory variable of Prague's spatial voting patterns is the distance from the city centre. The study therefore suggests applying the zonal sociological model of the city to studying, analysing and explaining urban electoral geography.

Following upon that study of voting in Prague, the goal of this article is to explore and compare spatial voting behaviour patterns in two metropolises and discuss possible explanation of the patterns in the Burgess zonal model of city.

\section{Votes and the city}

Even though the urban environment has not attracted much attention in electoral geography, in addition to the large number of studies exploring states 
and regions, there are some publications where cities are analysed. In order to better understand the current status of intra-urban electoral geography, in this section I offer short review of up-to-date literature.

As noted above, there is no standardised methodological or theoretical approach to studying the electoral geography of cities. Nevertheless, some thematic categories have been identified in the electoral geography of cities to

date. These can be categorised as follows:

- correlation and descriptive research,

- effect of suburbanisation,

role of minorities,

- effect of campaigning.

\section{Correlations and descriptive research}

The first electoral geography work dealing with the city, as a smaller territorial unit, dates back to 1936, when Gosnell - Schmidt (1936) investigated elections in Chicago. The authors aggregated the election results from the 1928 to the 1934 congressional elections, and the census and referenda data on a common level of 147 territorial units, that were then analysed using correlation methods. Despite the ambitious work of the authors, the only goal of their study was the comparison of two statistical methods.

A fascinating electoral geographical study of its time was O'Loughlin et al.'s (1997) text depicting the spatial polarisation of Muscovites shortly after the fall of the communist regime and the collapse of the Soviet Union. The Russian-American team of authors focused on the 1993 and 1995 State Duma elections and the 1996 presidential election. The O'Loughlin et al. (1997) publication is undoubtedly among the pioneer texts in the field of urban electoral geography, not just because their study of the city combined both compositional and contextual approaches, but also because it was the first and is the only electoral geographic publication in the post-Soviet region after the fall of the regime in which free elections have not been conducted for a long time. In addition, very ambitiously, it studied the capital city of the entire former Eastern Bloc. The authors conclude that there is strong polarisation in Moscow reflecting the deepening social conflict between the 'winners' and 'losers' of the economic transition from a state-run to a market economy. They observed a difference between the rich centre and prefabricated (khrushchevka) ghettos, which at that time were in very bad physical condition. Unsurprisingly, the strongest polarisation in Moscow was an economic cleavage characterised primarily by the attitude to the economic transition.

Another pioneering work in urban electoral geography in Central Europe is the Atlas of Warsaw (Węcławowicz et al., 1998). In this, the authors draw a map of the electoral wards of the metropolis of the Third Republic of Poland 
and then visualise the results of the 1991 and 1993 parliamentary elections. They observe strong spatial polarisation and discover the concentration of local interests in some areas of post-communist Warsaw. The Atlas of Warsaw is a typical example of a compositional approach. The authors seek to find associations between socio-economic data and electoral results; however, they do so without a detailed theoretical background or explanation.

Regarding Central Europe, we must note publications dealing with the capital of Slovakia - Bratislava. One of them is Bahna - Majo's (2012) work on the 2010 and 2012 parliamentary elections. The authors draw and visualise the city of Bratislava at the micro-level of 178 electoral wards. From the point of view of urban electoral geography in Slovakia, this can be considered a pioneering study.

Bahna - Majo's (2012) goal was to ascertain whether the variation of electoral support could be explained by a variation in socio-demographic characteristics. Despite the methodological limits, when they roughly transferred socio-demographic data aggregated in 18 administrative divisions to 178 electoral wards, the authors concluded that some socio-demographic characteristics had an explanatory potential for variation in the electoral behaviour of Bratislava voters.

Work by Bahna - Majo (2012) is one of compositional electoral geography, but - similar to the studies described above - without a deeper theoretical grounding. However, the authors did find that variations in electoral behaviour in Bratislava are related to the type of built-up area. Areas of family houses or older residential neighbourhoods tended to support more right-wing parties. More recently built areas tended to vote for liberal parties.

A description of Bratislava's electoral geography is also offered in Plešivčák's (2013) chapter in the book on human geography of Bratislava. Plešivčák (2013) maps the elections in Bratislava in terms of voting dynamics over time; however, he fails to provide an empirical explanation of the spatial variation of voting. An aggregation of electoral data at the level of 18 administrative divisions of the city of Bratislava is used.

Among research on Slovak cities, it is appropriate to mention a publication on the second largest Slovak city, Košice (Kerekes 2018b). Electoral behaviour in Košice during the 2016 parliamentary elections was examined, using a composite approach, theoretically grounded in the cleavage theory. As a result, only the centre-periphery conflict, as conceptualised in Lipset - Rokkan's (1967) theory, can explain the spatial variation of voting in Košice, especially in relation to nationally and ethnically oriented parties.

In cartograms (Kerekes 2018b) author observes distinctions between various parts of Košice, in particular, differences between the historical, residential and mass housing areas dating to various periods. While the historical part of 
Košice tends to vote for the Hungarian parties, the residential parts tend to vote for right-wing and conservative parties. Older prefabricated mass housing estates tend to vote for left-wing parties and more recent prefabricated housing estates tend to support more radical parties.

In the descriptive electoral geographic research of cities, a comparative study examining the 2016 parliamentary elections in Bratislava and Košice (Bahna et al. 2018) should be mentioned. The text tries to be methodologically innovative, in addition to describing and visualising the spatial variation of electoral behaviour in the urban environment of Bratislava and Košice. The authors compared intra-urban changes in voter attitudes with previous elections, using the ecological inference method.

A monograph describing and visualising the interwar electoral geography of Budapest (Ignácz 2013) is definitely worth noting in terms of Central European research. Unfortunately, its findings are not summarised here, due to the language barrier.

Gutoia's (2018) study is worth a mention in terms of Romanian electoral geography. Gutoia (2018) analyses the case of Bucharest using spatial econometrics. Data from a total of 278 polling stations were used. The author comes to a similar conclusion to Kerekes $(2018 \mathrm{a}$; 2018b) that the spatial polarisation of electoral behaviour showed the characteristics of a zonal structure. Gutoiu (2018) stated that Bucharest's inhabitants were polarised into the precommunistic old town and its surrounding areas built mainly during the time of socialism. The author even states that the polarisation is stronger than that based on the socio-demographic structure of the inhabitants. It needs noting that Gutoiu (2018) also criticises the lack of development of the electoral geography theory that would be able to explain the spatial variation of electoral behaviour, especially for urban electoral geography.

\section{Effect of suburbanisation}

The massive suburbanisation that began in the 1960s in capitals across the globe, of course, also attracted the attention of researchers. Research into suburbanisation and its impact on spatial patterns of electoral behaviour is not strictly a field of urban electoral geography, though it is closely related. In addition, suburbanisation research focuses more on electoral dynamics than on static spatial patterns.

The very first studies showing the dichotomy between the left-wing central city and its right-wing suburbs date from the late 1940s in the United States (Greenstein - Wolfinger 1958; Harris 1954; Janosik 1956; Lazerwitz 1960; Whyte 1956). The authors also note the strengthening of Republicans in suburban areas. However, this is attributed to the selective withdrawal of 
already identified Republican voters into suburbia, rather than the conversion of Democratic Party voters after moving.

A pioneering study on the suburbanisation effect in Europe is Cox's (1968) analysis of the London metropolitan area. Cox (1968) examined the effect of suburbanisation on London's changing electoral map and identified direct and indirect effects. Cox (1968) noted Labour-voting central London and Conservative-voting suburban London. The dichotomy has been explained and empirically proved by two theories, or hypotheses, respectively. The first is the conversation hypothesis. Labour voters were changing their economic status after moving to the London suburbs. They suddenly owned real estate and paid property taxes that they had not paid before. Then there is the impact of the environment, meaning that families with children were more likely to socially interact, and their interactions were much more intense in suburbia than they had been in central London. That is the so-called neighbourhood effect. Finally, Cox (1968) argues that Conservative policies and communications were targeted at suburban Londoners, for instance, on tax issues. The second hypothesis is the transplantation hypothesis. Voters who identified as Conservative were more likely than those identifying as Labour to move from central London to the suburbs. Therefore, suburbanisation was seen as a sort of self-selection of Conservative voters.

Walks (2005) analysed more comprehensively the dichotomy between intraurban and suburban electoral behaviour in Great Britain of the post-war era. As with the previous authors, Walks (2005) identifies the Labour inner city and the Conservative suburbs. Continuing the research, Walks $(2004,2006)$ examines the dichotomy in Canadian cities and confirms the hypothesis of the right-wing suburb and left-wing inner city. Walks $(2004,2005,2006)$ describes two phenomena. The first is the self-selection of Conservative voters in the process of suburbanisation. In other words, it is the voter who identifies as right-wing who seeks to live in residential housing on the outskirts of the city. Then, according to Walks $(2004,2005,2006)$, these voters are looking for a social environment that is closer to their values and attitudes. The second phenomenon is the influence of the neighbourhood and the subsequent conversion from left-wing identification to right-wing.

Gainsborough (2005) points out that even voters with the same individual characteristics vote differently depending on whether they live in the city or in the suburbs. On the example of the US presidential election, the author demonstrates the tendency of intra-city voters to vote for Democratic candidates. The phenomenon is caused by the way voters evaluate policies. According to Gainsborough $(2001,2005)$, urban and suburban voters attribute different weights to the same policies. 
Maesschalck (2011) identifies similar patterns in Antwerp, Belgium. While Social Democrats are highly represented in the central city, Liberals dominate in the suburban parts of the metropolis. Maesschalck (2011) emphasises that the support for Liberals had gradually moved from the urban area into the suburbs. He attributes this to the anti-migration rhetoric of the Belgian Liberals (VLD), who portrayed the inner city as a place of crime. And they emphasised that they wanted a safe city for commuters. Social Democrats, on the contrary, defended the interests of the inner-city inhabitants.

Suburbanisation around Bratislava was studied by Šuška et al. (2018) and Šuška et al. (2019). Their findings correspond with the those mentioned above. Suburbanisation around the Slovak capital leads to better gains for right-wing conservative parties on the suburb.

\section{Role of minorities}

The role of sexual, ethnic or other minorities forms a significant part of the research into urban spatial patterns of voting. The reason for many such articles might be the absence or poor availability of sociological spatial data. Cities are full of sociological phenomena that cannot be quantitatively or spatially explored because of the limits in operationalisation.

Lewis (1965) came up with one of the breakthroughs in the field, describing by cartographic analysis the influence of the Afro-American minority on the electoral geography of Flint, Michigan. In addition, Lewis's (1965) study offers extensive description and - ambitiously for its time - advanced visualisations in cartograms. He emphasises the cartograms as an important tool for exploring the spatial patterns of electoral behaviour in cities.

In principle, Lewis (1965) did not present Earth-shattering findings, which were basically identical with the findings of research on the impact of suburbanisation on the electoral map - the Republicans lost their support in the central city, especially after several years of ongoing Afro-American immigration into the city and the continuous move of rich white inhabitants into the suburbs. However, the study is remarkable in its attention to detail and the micro-level at which it describes the phenomenon. The study is also beneficial for the methodology of visualisation and data analysis.

A decade later, Salter and Mings (1972) looked at the Cuban minority in Miami-Dade County, Florida. Using cartographic analysis, the authors tried to predict how large the Cuban minority would be in the given territory and to what extent the minority would affect the Miami-Dade electoral map. Salter Mings (1972) concluded that Miami would no longer be a traditional Democratic city because the Cuban minority would seek out candidates with a strong anti-communist stance. 
Salter and Mings's (1972) work provides excellent and detailed visualisations of urban electoral data in cartograms. The publication is also fascinating for the inverse approach the authors apply. Normally, electoral geographic research is aimed at explaining the spatial patterns of electoral support for political parties, applying a non-spatial theory of electoral behaviour. In this case, however, the authors proceeded to the contrary, using the spatial variation of aggregated data to explain electoral behaviour.

Salter's and Mings's (1972) prediction proved not to be entirely accurate. Webster and Webster (1987) tried to verify the prediction and proved that the increase in the success of the Republican party was powered by the Hispanic minority rather than Cuban. Webster and Webster (1987) also stressed the presence of a spatial distinction, which was strongly correlated with the presence of an ethnicity in territory. Thus, Hispanics tended to vote Republican while Afro-Americans voted for the Democrats.

Migration and its impact on the electoral map were also addressed by Sonenshein and Drayse (2006). The authors found that the formation of electoral coalitions based on ethnicity and race was present. Such coalitions were created repeatedly, appearing in particular areas. With the increasing spatial concentration of ethnic groups, the effect was reinforced further.

Borisyuk et al. (2007) obtained unique electoral and socio-economic data aggregated to a common level of 624 territorial units, identical with the territory of the London wards, for elections to the European Parliament. The authors found that while the spatial distribution of support for traditional large British parties was homogeneous in London, it was quite the opposite for minor parties. Borisyuk et al. (2007) found that the spatial variation of minor but electorally successful parties (Respect, Green, UKIP and the British National Party) could be explained, for example, by the spatial distribution of religious groups.

A recent study by Nathan (2016) examines the urban space in Ghana. According to Nathan (2016), the spatial variation of electoral behaviour in African countries can be quite simply explained by the spatial variation of ethnic groups. The party system in Ghana is, as well, split along ethnic lines. However, according to Nathan (2016), this does not apply to intra-urban spatial variation of electoral behaviour. The urban spatial variation of votes overcomes ethnic and individual characteristics that would otherwise be able to explain the variation. On the contrary, the author points out that the neighbourhood and its characteristics play a significant role.

\section{Effect of campaigning}

The effect of campaigning on the geography of election results is an area that usually attracts sociologists and political scientists rather than electoral 
geographers, especially in the case of urban electoral geography. Consideration was given to whether this topic deserved a separate category in this review. However, as it is a very specific field of urban electoral geography that could not be included in previous categories, it was given its place, despite the fact that there are only a few studies concerned with it. A study describing the impact of local policies on Chicago's electoral map (Kasperson 1965) is worth a mention in this section. Kasperson's (1965) study suggests that politics and electoral behaviour in Chicago have a zonal structure.

Similarly, Rumley and Minghi (1977), based on the Kasperson (1965) study, also suggested a basic framework for studying spatial patterns of electoral behaviour in cities; and they also emphasised the effect of election campaigns. Subsequently, the effect of campaigning on spatial patterns was tested in Vancouver, Canada (Minghi - Rumley 1978). The authors admit that the campaigning effect is likely to operate; however, measuring it is extremely difficult.

An entirely different approach to the electoral geography of cities was chosen by Brown et al. (2005), who did not examine whether the spatial distribution of the results of the elections correspond to the representation of social groups. On the contrary, Brown et al. (2005) examined whether and to what extent elections establish new social groups and whether they can be distinguished geographically. In particular, the authors focused on the impact of public and political discourse that had been taking place around an anti-gay referendum in Tacoma. Using cluster analysis, they identified certain newly formed electoral social groups, cutting across the traditional social class structure. The work of Brown et al. (2005) was undoubtedly innovative in terms of the post-structural approach that the researchers undertook. This is an exceptional phenomenon in electoral geography, especially in urban electoral geography.

\section{The sociological model of the city}

There are four main traditions in explaining voting behaviour. The sociological school, the psychological school, the economic school, and the issue voting. The compositional approach - one dominating electoral geography research is based on a sociological tradition of electoral behaviour. According to the tradition (Berelson et al. 1954; Katz - Lazarsfeld 1955; Lazarsfeld et al. 1944), voters make electoral decisions on the basis of the influence of the social group they belong to.

The elementary premise of the composite approach is that the spatial variation of the vote varies together with the representation of social groups in the territory. In other words, if a party gains more votes in one territory than in another, it is because the social group the party is associated with is more 
represented in the territory. The patterns of territorial support for political parties thus follow the patterns of representation of particular social groups.

Should we wish to find a wider-ranging explanation of the spatial variation of voting behaviour in the city, a more comprehensive approach is needed. Thus, the compositional approach seems to be better suited to this than the contextual one, which is not sufficiently comprehensive. That is the reason why I narrow this article only to sociological tradition, despite od the fact that sociological tradition does not explain all the electoral behaviour and other approaches could be able to contribute to explaining the spatial variation of votes.

Nevertheless, the electoral geography research in the Czech Republic shows that the sociological tradition and the compositional approach still explain the most of spatial variation of the voting behaviour at the national level (e.g. Kostelecký et al. 2014; Kostelecký et al. 2015; Šimon 2015; Pink 2018).

So far, electoral geography has been satisfied with identifying social groups in a territory and then correlating them with election results. Based on such correlation associations, conclusions are drawn. However, such a procedure is too descriptive and insufficiently explanatory. Basically, all it does is adding a spatial dimension to previously explained theoretical relationships.

However, electoral geography, and especially urban electoral geography, is only minimally concerned with whether social groups are randomly distributed in space. In the case of large territories, such as states, electoral geography has been helped in particular by Lipset's and Rokkan's cleavages theory (1967), which to some extent explains not only the existence of social groups and political parties but also their non-random distribution. However, in urban electoral geography, this theory is inapplicable. For obvious reasons.

Descriptive and correlational urban electoral geography research has been satisfied with the description of spatial variation associations of voting support and social groups. However, the question of how and why social groups are distributed in space remained overlooked. This aspect has been covered only by research into suburbanisation, which, inherently, has to deal with the issue of distribution of social groups. However, while research into the impact of suburbanisation on spatial patterns of electoral behaviour has examined a particular phenomenon, it has not offered a holistic view of the city's electoral geography.

In this article, I aspire to go a little further. Urban sociologists assume that a city has some conceptual sociological structure. Best-known of the models is the Concentric Zone Model (Burgess 1925). Burgess (1925) developed this model on the example of Chicago's social development. According to the model, around the central city there are concentric zones occupied by specific social groups. These zones are the result of permanent social conflict in the 
urban space, with some social groups pushing others out. This results in zonal equilibrium.

The model (see Figure 1 below), divides the city into several zones. The first, the Central Business District, is characterised by high rents and business profitability. It is densely built-up and easily accessible by public transport. Next is the Transition Zone of commercial property mixed with residential housing. The Transition Zone is also characterised by high population density, and old and dilapidated buildings. According to Burgess (1925), the Transition Zone is the former industrial part of the city, which is also characterised by poverty. The Transition Zone is surrounded by the Working Class Zone or inner suburbs, characterised by a mixture of old and modern developments occupied mainly by the working class. The conditions are better than in the Transition Zone. The zone is established mainly by the migration of the working class to the city to reduce the cost of commuting. The next zone is the so-called White Collar Home or outer suburbs - a residential area inhabited by middle-class families and characterised by better amenities. The zoning is completed by a commuter zone inhabited by wealthier residents. Typical of this zone are large family houses.

\section{Figure 1: Concentric Zone Model}

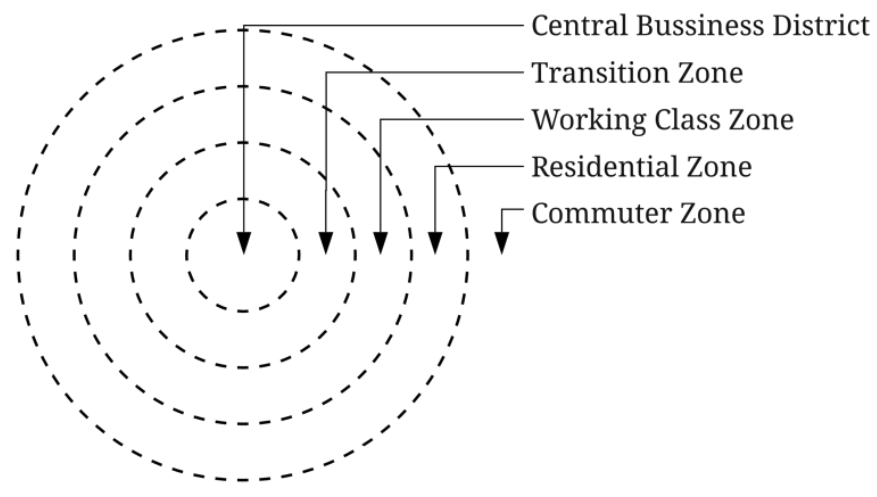

Source: Burgess (1925)

The Burgess model is the base for urban sociology approach well known as the Chicago school. There are two newer models within the school - Sector Model (Hoyt 1939) and Multiple Nuclei Model (Harris - Ullman 1945). Both models, however, develop the Burgess model to be better fit to Chicago terrain and topography. As Meyer and Esposito (2015) state the all three models are complementary. In this paper I suggest seeking the explanation of spatial distribution of votes in the zonal model. The reason is its simplicity, generality and thus its applicability on other cities. 
The concentric model, of course, faces criticism. Especially from some scholars know as Los Angeles school. Mainly because it is already outdated and does not correspond to the current urban development (Dear 2001, 2003). On the other hand, Meyer and Esposito (2015: 1) consider the Los Angeles school's criticism as "more on assertion than on evidence". The persistence of the zonal structure and in some cases its strengthening was confirmed by empirical studies in American (Shearmur - Charron 2004; Meyer - Esposito 2015) or Canadian (Balakrishnan - Jarvis 1991) cities.

Sure, the applicability of the model in explaining the spatial distribution of social classes in European cities that obviously experienced different historical developments, evokes doubts. Nevertheless, American cities have been developing for only half a millennium so far, even the oldest, while European cities have a much longer history.

However, studies analysing non-European cities (e.g. Moscheles 1937; William-Olsson 1940; Beynon 1943; Hauser 1951; Castle - Gittus 1957; Collison - Mogey 1959; McElrath 1962; Abbott 1974) show that cities out of the American continent follow the zonal structure as well. Although not necessarily in the same order as suggested by Burgess (1925). The work of Ouředníček et al. (2012) proves that Prague does show the zonal structure.

If the electoral behaviour could be explained, at least in part, by the sociological theory of voting, and if the Michigan school could explain, at least in part, the spatial distribution of social groups in urban area, then the spatial patterns of electoral behaviour in the city could reflect the zonal structure. Thus, the Burgess model and its theory could serve as a basis for explaining the geographical patterns in voting.

Warsaw and Prague were chosen for this paper deliberately. Warsaw was flattened by bombing in 1945. Subsequently, it was rebuilt and settled almost completely anew. This inevitably meant breaking the centuries-long social continuity and hence also the placement of social groups. After the destruction of the city, a new social continuity has been launched.

In many respects, Prague is similar to Warsaw, but with the difference that Prague survived WWII and its social-space continuity was not interrupted in such range. So, it can be assumed that the concentric arrangement of the city might be clearer in the case of Prague. In Warsaw, the population might be expected to be more homogenous, since social conflict over the territory has not yet been completed.

\section{Data and methods}

\section{Cases and variables}

This article investigates the capital cities of the Czech Republic and Poland. The electoral support of political parties that have obtained at least $3 \%$ of the 
valid votes cast in the city in the most recent elections to the lower houses of parliament are used as spatial variables for the analysis: in the case of Prague, the elections to the Chamber of Deputies in October 2017 and in the case of Warsaw the elections to the Sejm in October 2015. Tables 1 and 2 below presents the list of such parties.

Table 1: Political parties in the analysis - Prague

\begin{tabular}{|c|c|c|c|}
\hline Abbr. & Party name & Party family & European affiliation \\
\hline ODS & Civic Democratic Party & Civic Democrats & $\begin{array}{l}\text { Alliance of Conservatives and } \\
\text { Reformists in Europe }\end{array}$ \\
\hline ČSSD & Czech Social Democratic Party & Social Democrats & Party of European Socialists \\
\hline STAN & Mayors and Independents & & \\
\hline KSČM & $\begin{array}{l}\text { Communist Party of Bohemia and } \\
\text { Moravia }\end{array}$ & Communists & Party of the European Left \\
\hline Piráti & Czech Pirate Party & Pirates & \\
\hline TOP 09 & TOP 09 & Conservatives & European People's Party \\
\hline ANO 2011 & ANO 2011 & & $\begin{array}{l}\text { Alliance of Liberals and } \\
\text { Democrats for Europe Party }\end{array}$ \\
\hline KDÚ-ČSL & $\begin{array}{l}\text { Christian and Democratic Union - } \\
\text { Czechoslovak People's Party }\end{array}$ & $\begin{array}{l}\text { Christian } \\
\text { Democrats }\end{array}$ & European People's Party \\
\hline SPD & $\begin{array}{l}\text { Freedom and Direct Democracy - } \\
\text { Tomio Okamura }\end{array}$ & Populists & $\begin{array}{l}\text { Movement for a Europe of } \\
\text { Nations and Freedom }\end{array}$ \\
\hline
\end{tabular}

Source: Author's elaboration

The choice of the $3 \%$ threshold was made to eliminate marginal parties that, at the same time, show poor spatial variance, and so are unsuitable for the analysis. The timing of cases is related to the topicality and availability of data. In both cases, these are the most recent first-order elections. As far as data availability is concerned, I am particularly interested in data on defining the boundaries of electoral wards. In both cities, this definition is the competence of the local district municipality offices. In the case of Prague, the 2017 elections were the very first in which wards were defined in the geographic information system (GIS), so they were easy to process. In the case of Warsaw, however, manual processing from textual definition to geographical coordinates was needed to conduct the analysis. This was done by assigning the wards numbers to specific address points, which, fortunately, were defined in the GIS and publicly available. Otherwise, the analysis on such a subtle level, which is crucial for developing the urban electoral geography, would be almost impossible. 
Table 2: Political parties in the analysis - Warsaw

\begin{tabular}{llll}
\hline Abbr. & Party name & Party family & European affiliation \\
\hline PiS & Law and Justice & Conservatives & $\begin{array}{l}\text { Alliance of Conservatives and } \\
\text { Reformists in Europe } \\
\text { European People's Party }\end{array}$ \\
PO & Civic Platform & Liberals/Christian Democrats & Social Liberals \\
Razen & Together & Populists & \\
KORWiN & Korwin & Socialists & Party of European Socialists \\
ZL & United Left & Populists & \\
K'15 & Kukiz'15 & Liberals & Alliance of Liberals and \\
.N & Modern & & Democrats for Europe Party \\
\hline
\end{tabular}

Source: Author's elaboration

At the outset, a basic description of the spatial variation of support for particular political parties is undertaken. This is measured by the coefficient of variation $(\mathrm{CV})$, which is calculated as the ratio of standard deviation and mean. The statistical unit is represented by the outcome in an electoral ward. Election results were obtained from the Czech Statistical Office (ČSÚ) and on request from the State Electoral Commission of the Republic of Poland (PKW).

\section{Component analysis and visualisation}

Component analysis was performed to reduce the number of variables and to identify a principal spatial polarisation of vote shares in the analysed cities. The reduction was conducted using IBM SPSS application and, as I decided to use only the first components, there was no need for rotation. A score for each ward, extracted by the regression method, was used as a variable representing the polarisation.

Map visualisation was conducted using address points. This made the visualisation significantly different from other works in electoral geography, where the visualisation of electoral support in space is done by cartograms using polygons.

However, visualisation of urban electoral data in polygons is impractical and confusing. The size of the polygon depends on the territorial administrative division of the territory; in this case particularly on the size of the electoral ward. Some parts of the city, usually central, are, however, densely populated and settled, but the outskirts of the city are more sparsely built and inhabited. In such a case, the polygons in the central part of the city are much smaller, even though they are not less significant in the dataset. Conversely, polygons in less built up and less densely occupied locations are then disproportionately large and confusing when visualised. 
In the case of Prague, the address points were approximated from the data on locations of buildings obtained from the Cadastral Office of the Czech Republic (ČÚZK). These data were then combined with data on buildings extracted from the OpenStreetMaps platform to correct possible mistakes in the data. The dataset was then filtered down to those buildings intended for housing to best represent inhabited areas. The address points were allocated electoral ward numbers according to where the point lay. The polygon layer defining the electoral wards was obtained from ČZÚK.

In the case of Warsaw, the locations of the address points were obtained from the City of Warsaw Office. The numbers of electoral wards were manually attributed to the specified address points according to information on the delimitation of electoral wards published on the official website of the City of Warsaw Office. The address points were then filtered down to those inhabited by voters. Subsequently, the component analysis scores were attributed to address points. The map visualisation uses 5-level Jenks' intervals. The map projection is created in a pseudo WGS 84 system.

\section{Distance}

The distance out of the city was measured as the road distance from the city centre to the point that represents the mean latitude and longitude of the address points located in the ward. Road distances were measured using Google Maps API.

In the case of Prague, the Old Town Square (Čtyroký 2017) with the coordinates 50.087604, 14.421134 was selected as the city centre; and in the case of Warsaw, the public transport node Centrum, namely the middle point of the Dmowski roundabout with the coordinates 52.229827, 21.011742, was selected as the city centre for the purposes of this analysis.

The results were visualised in scatterplots, where the vertical axis represents a factor score and the horizontal axis the distance in kilometres. A Loess' fitline (50\% of points) is provided in the scatterplots to identify trends in associations between distances and factor scores. All measurements in this study are conducted using the WGS 84 coordinate system.

\section{Results}

The tables below compare national-level electoral results with the results of the cities of Prague and Warsaw. Obviously, right-wing, conservative and liberal parties were doing better in Prague. The Civic Democrats (ODS) gained approximately five percentage points more in Prague than nationwide. Pirates and TOP 09 gained seven percentage points more. On the contrary, in the city, the Communists, the nation-wide winner (ANO 2011), and the populists from 
SPD lost. The biggest difference between Prague and the national results is manifested in the support for ANO 2011: up to nine percentage points.

Table 3: Comparison of Prague and nationwide results and variation

\begin{tabular}{llllll}
\hline Party & $\begin{array}{l}\text { Nationwide } \\
\text { Result }(\%)\end{array}$ & $\begin{array}{l}\text { Prague } \\
\text { Result }(\%)\end{array}$ & Mean & STD & CV \\
\hline ODS & 11.32 & 16.22 & 16.04 & 3.24 & 0.202 \\
ČSSD & 7.27 & 6.63 & 5.63 & 1.77 & 0.314 \\
STAN & 5.18 & 5.05 & 4.97 & 1.68 & 0.338 \\
KSČM & 7.76 & 4.60 & 4.67 & 2.49 & 0.534 \\
Piráti & 10.79 & 17.59 & 17.67 & 2.86 & 0.162 \\
TOP 09 & 5.31 & 12.64 & 12.73 & 4.07 & 0.320 \\
ANO 2011 & 29.64 & 20.35 & 20.25 & 5.10 & 0.252 \\
KDU-ČSL & 5.80 & 4.76 & 4.79 & 1.73 & 0.362 \\
SPD & 10.64 & 5.81 & 5.82 & 1.79 & 0.308 \\
\hline
\end{tabular}

$\mathrm{N}=1,108$; Source: Czech Statistical Office, author's calculation

Mayors and Independent and, to a lesser extent, the Social Democrats, showed similar support in the city as at the national level. In terms of the spatial variation of electoral support in the city, the Communists were the most heterogeneous of the observed parties. On the contrary, surprisingly, the Pirates had the lowest level of spatial variation.

A similar situation was found in Warsaw, where there was a different political cleavage. The rightist conservative party Law and Justice was about eight percentage points weaker in Warsaw than nationwide. On the contrary, liberal parties did better in Warsaw than in Poland generally. Notably, the Modern Party obtained twice as much support in Warsaw as it did in the country as a whole.

Table 4: Comparison of Warsaw and nationwide results and variation

\begin{tabular}{llllll}
\hline \multirow{2}{*}{ Party } & Nationwide & Warsaw & & \\
\cline { 2 - 6 } & Result $(\%)$ & Result $(\%)$ & Mean & STD & CV \\
\hline PiS & 37.58 & 29.19 & 30.32 & 7.30 & 0.241 \\
PO & 24.09 & 29.23 & 29.10 & 4.09 & 0.141 \\
Razem & 3.62 & 5.55 & 5.48 & 1.42 & 0.259 \\
KORWiN & 4.76 & 4.98 & 4.86 & 1.40 & 0.288 \\
ZL & 7.55 & 9.30 & 9.21 & 2.81 & 0.305 \\
K'15 & 8.81 & 6.33 & 6.41 & 2.12 & 0.331 \\
. $\mathrm{~N}$ & 7.60 & 14.18 & 13.33 & 5.08 & 0.381 \\
\hline
\end{tabular}

$\mathrm{N}=887$; Source: State Electoral Commission, author's calculation 
In terms of spatial variation, the Civic Platform was the most homogeneous, and, on the contrary, support for the Modern Party varied the most in Warsaw, among the parties examined.

\section{Component analysis}

Since the Czech and Polish party systems both contain a large number of parties, a component analysis was conducted in an attempt to reduce the number of analysed variables. The results of the analysis are presented in Table 5 and Figures 2 and 3. The component analysis of the election outcomes in electoral wards actually shows the main and the strongest spatial polarisation of voters in the cities.

Table 5: Component Analysis

\begin{tabular}{|c|c|c|c|c|c|c|c|}
\hline \multirow{3}{*}{ Component } & \multicolumn{3}{|c|}{ Prague } & \multicolumn{4}{|c|}{ Warsaw } \\
\hline & \multicolumn{3}{|c|}{ Initial Eigenvalues } & \multirow{2}{*}{ Component } & \multicolumn{3}{|c|}{ Initial Eigenvalues } \\
\hline & Total & $\%$ of Variance & Cumulative $\%$ & & Total & $\%$ of Variance & Cumulative \% \\
\hline 1 & 3.650 & 40.550 & 40.550 & 1 & 2.081 & 29.726 & 29.726 \\
\hline 2 & 1.348 & 14.983 & 55.534 & 2 & 1.664 & 23.765 & 53.491 \\
\hline 3 & 1.012 & 11.247 & 66.781 & 3 & 1.234 & 17.634 & 71.125 \\
\hline 4 & 0.844 & 9.382 & 76.163 & 4 & 0.887 & 12.674 & 83.799 \\
\hline 5 & 0.680 & 7.556 & 83.719 & 5 & 0.617 & 8.821 & 92.620 \\
\hline 6 & 0.552 & 6.129 & 89.847 & 6 & 0.512 & 7.311 & 99.931 \\
\hline 7 & 0.527 & 5.852 & 95.699 & 7 & 0.005 & 0.069 & 100.000 \\
\hline 8 & 0.356 & 3.960 & 99.659 & & & & \\
\hline 9 & 0.031 & 0.341 & 100.000 & & & & \\
\hline
\end{tabular}

$\mathrm{N}=1,108$ for Prague, $\mathrm{N}=887$ for Warsaw, Source: Author's calculation

Both cities have at least three components with an Eigenvalue higher than 1. However, in Prague component 1 is much stronger than the rest and represents over $40 \%$ of variance. The strongest component for polarisation in Warsaw represents about $30 \%$ of variance. The weaker component for Warsaw, in comparison to Prague, might be caused by the lower number of cases or polling stations, respectively. While Czech electoral legislation requires electoral wards to have about 1,000 voters, the Polish system allows as many as 2,000 voters per ward.

Nevertheless, I visualised components 1 and 2 to show the polarisation of electoral support for parties. In the case of Prague, the distinction of right wing vs. left wing is clear. Right-wing politics are represented by conservative TOP 09 and ODS, while the Social Democrats (ČSSD), Communists (KSČM) and the winner of the election, ANO 2011, are on the left wing (though whether ANO 2011 can be described as a left-wing party is debatable). 
Figure 2: Component Plot: Prague

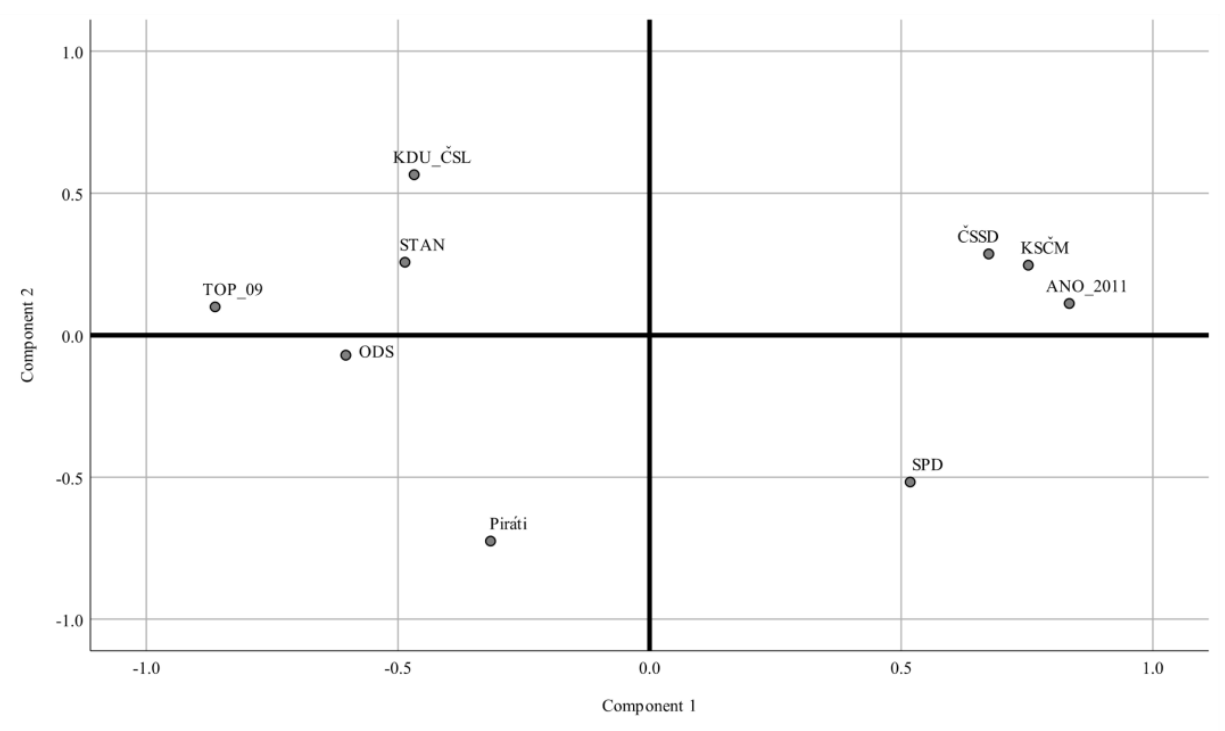

Source: Author's calculation

For Warsaw, the strongest spatial polarisation is represented by Law and Justice (PiS) on the one hand and by Modern (.N) and Civic Platform (PO) on the other. There is no doubt that the component represents the conservative vs. liberal distinction. In the case of Warsaw, loadings in the component are quite marginal, especially for PiS, whose value is very close to -1 .

In the cases of both Prague and Warsaw, component 2 represents something that might be called the distinction between traditional or establishment parties and new or modern parties, especially when looking at the marginal representatives of component 2. There are Christian Democrats (KDU-ČSL) on the one hand and Pirates and the recently established populist SPD on the other. For Warsaw, the traditional side is represented by Civic Platform (PO) and the modern side by a group of recently established parties.

Nevertheless, in further analysis, only component 1 was examined for both Warsaw and Prague. The rationale behind this is that component 1 helped to reduce the number of variables and, at the same time, shows the spatial polarisation of votes that was identical with the main political cleavage in both countries. Therefore, component 1 can serve as a vicarious variable in the analysis. 
Figure 3: Component Plot: Warsaw

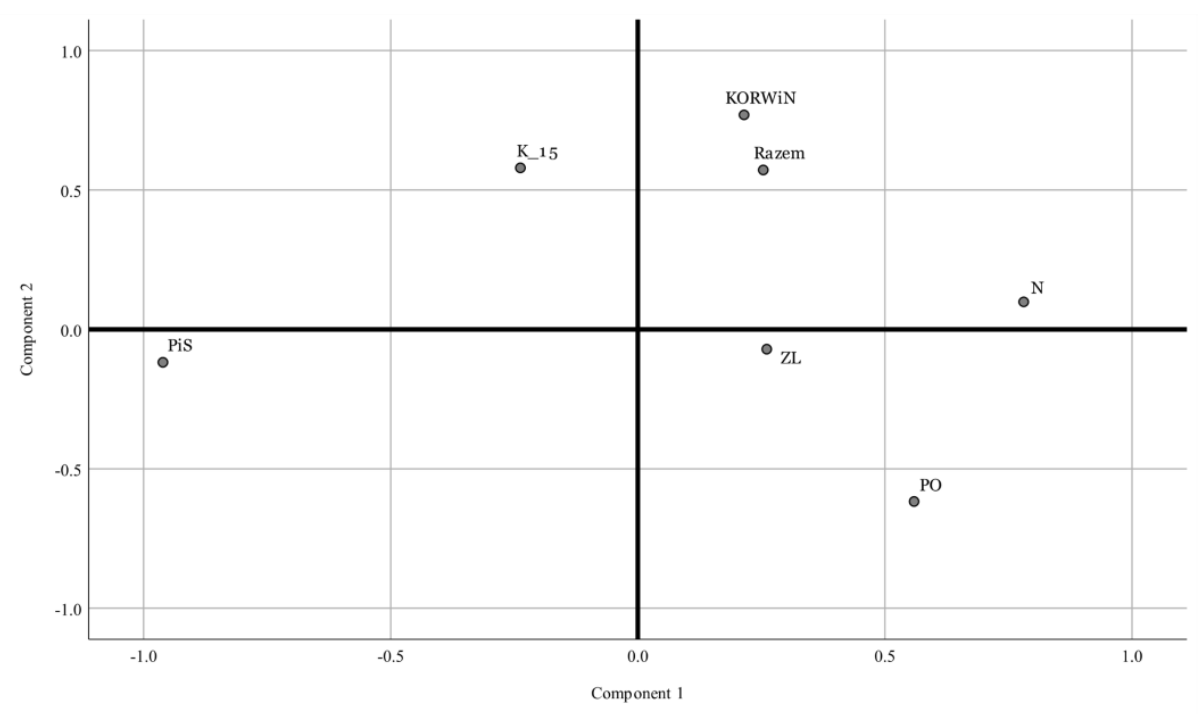

Source: Author's calculation

\section{Maps}

Figure 4 shows the distribution of the factor score for Prague. It might be said that it is a map of spatial polarisation of the electoral behaviour of the inhabitants of Prague. The light grey colour in this map represents a negative score - that is, support for right-wing conservative parties. Dark grey represents support for the socialists, communists and the winning ANO 2011.

At first glance, it is clear from the map that support for right-wing conservative parties tends to concentrate in the historical city centre. In addition, it is also present in some suburban parts of the city, such as Dolní Chabry, Suchdol, Křeslice, Lipenice and Slivenec.

Immediately surrounding the city centre are districts typically mixing light and dark address points with middle-dark points, the last representing an indifferent territory with respect to the analysed polarisation. Finally, there is a sort of dark left-wing orb, which lies over those parts of the city that are characterised by mass housing estates.

Figure 5 shows a map of electoral polarisation in Warsaw. The dark grey colour represents the territories tending to vote for the conservative winning party, while light grey shows support for more liberal parties.

The red colour, standing for conservative voters, tends to be concentrated on the eastern side of the Vistula river, but it is not rare on the western side either. In turn, support for liberal parties tends to be concentrated to the western side, 
as a belt starting in Bemowo, passing through Ochota and Mokotów to Ursynów, and these are areas characterised by residential mass housing development. Strong blue is also found in suburban areas in Białołęka and Rembertów.

Figure 4: Factor Scores in Prague

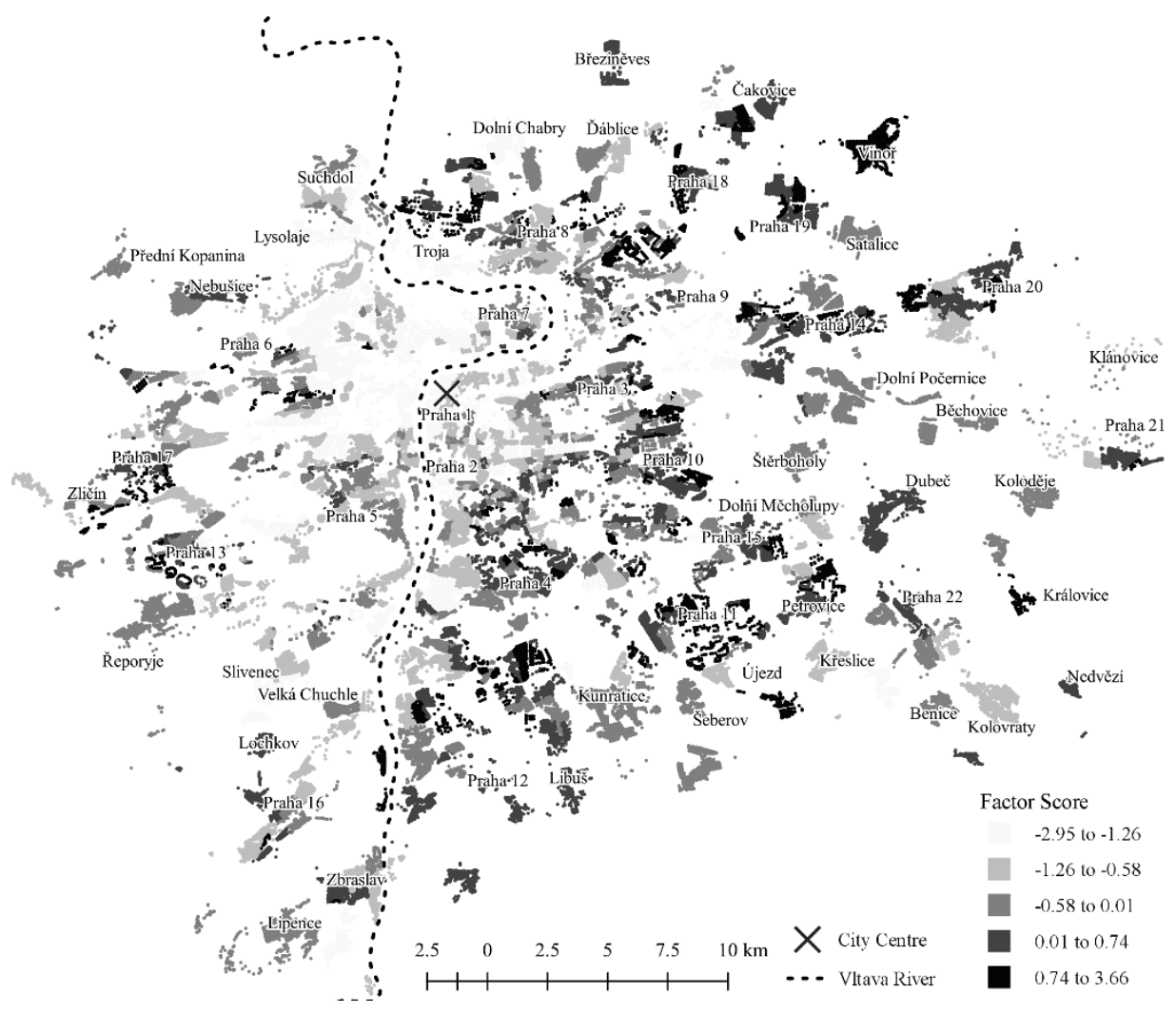

Source: Author's contribution

It is clear that the map does not show a zonal spatial structure of electoral behaviour. I certainly do not want to claim that the structure is random. This confirms my initial assumption in this study. While Prague has partially preserved the zonal structure of social groups, Warsaw, perhaps by being so heavily bombed, especially on the western side of the Vistula, has not retained such an arrangement; or rather, such an arrangement of social groups in space has not yet taken place. 
Figure 5: Factor Score in Warsaw

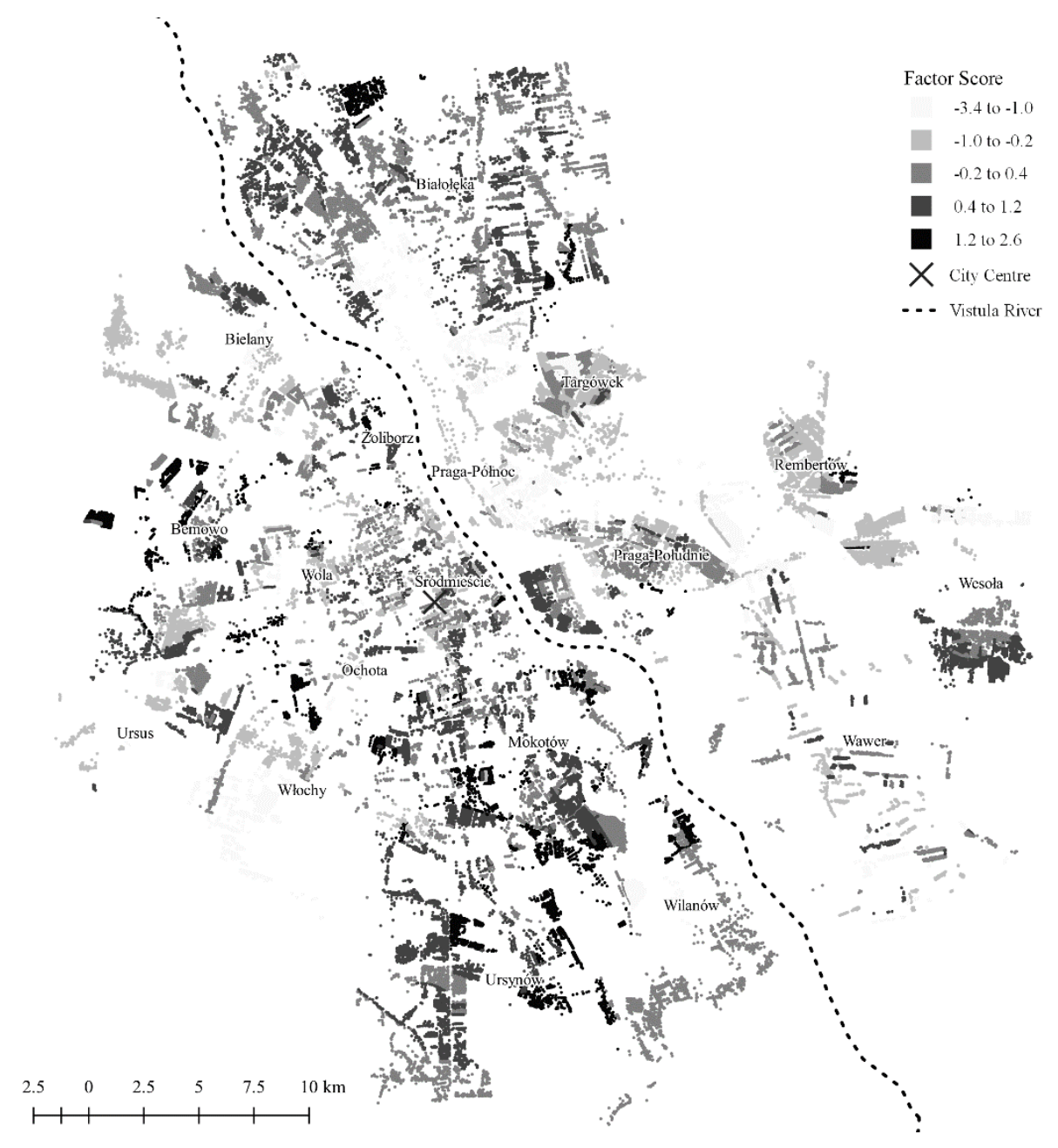

Source: Author's contribution

\section{Distance}

Figures 6 and 7 show associations between distance and factor scores for Prague and Warsaw. If we compare these scatterplots, it is obvious at first sight that the one for Prague shows different results than the one for Warsaw. The fit line in the case of Prague shows that the score rises sharply up to approximately 12 kilometres and then gradually decreases, but it no longer reaches such a low value as at the beginning. 
Figure 6: Scatterplot: Prague

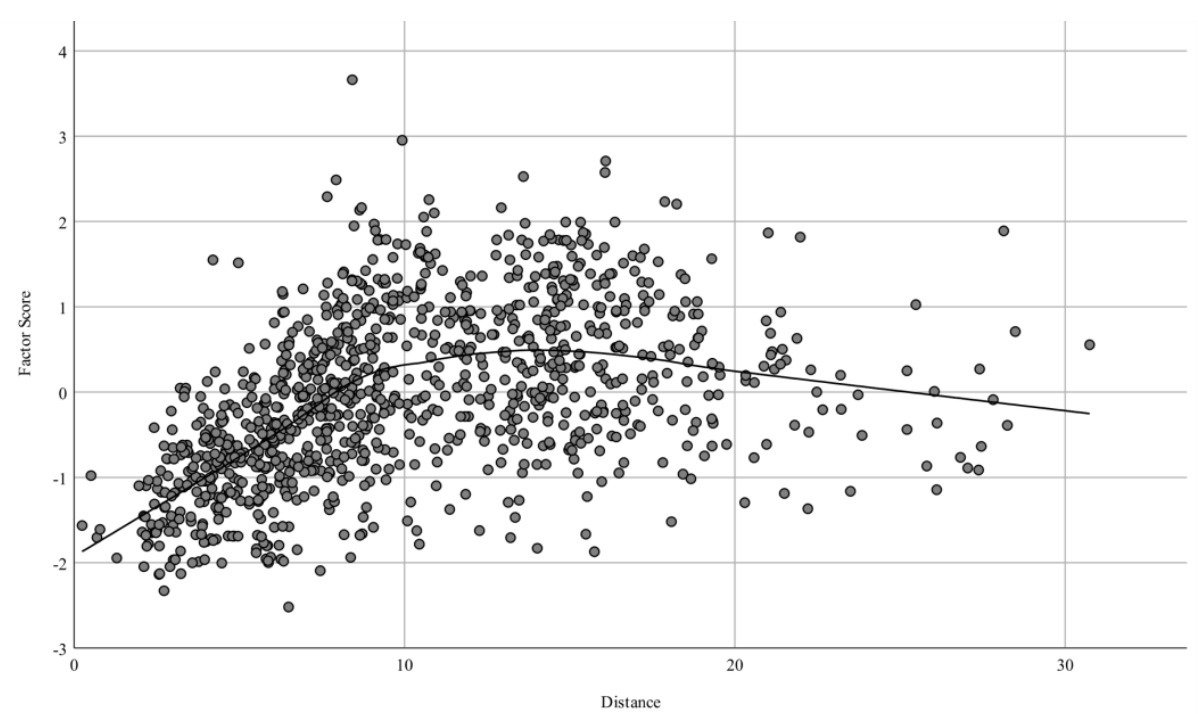

Source: Author's calculation

Figure 7: Scatterplot: Warsaw

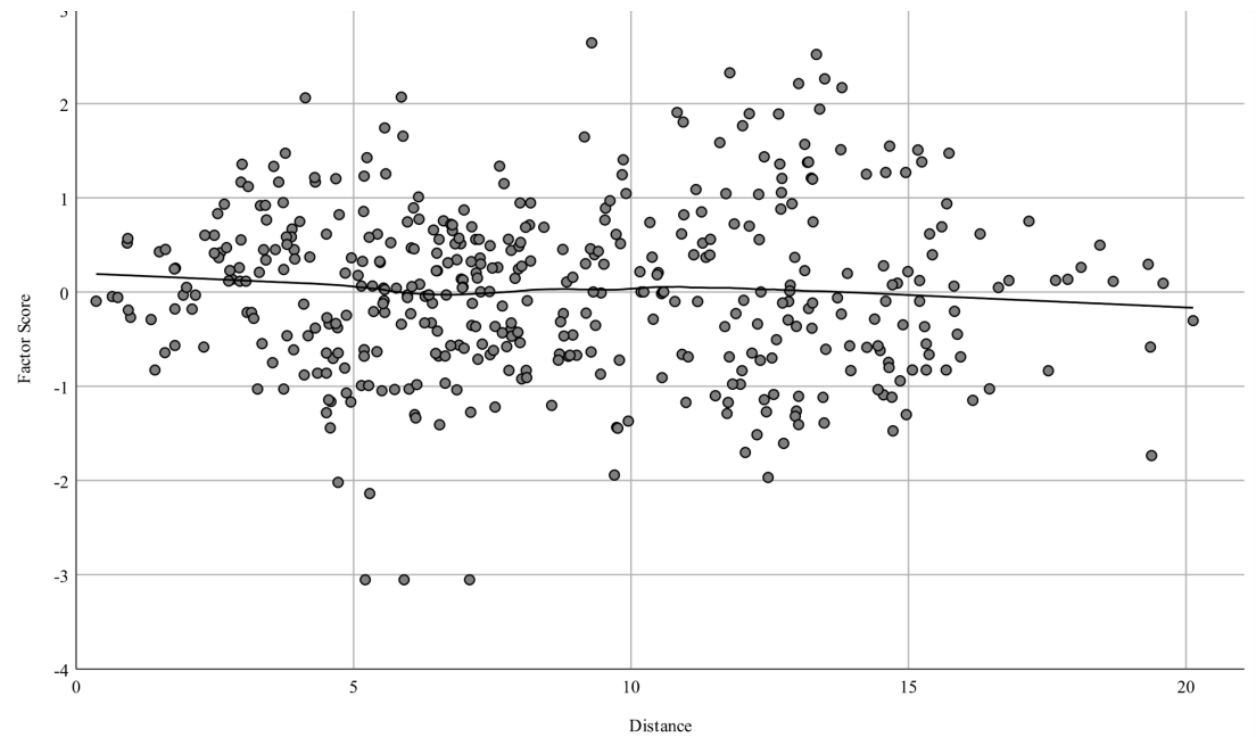

Source: Author's calculation 
It is therefore evident that the centre of Prague was strongly right-conservative, while with increasing distance from the centre, it quickly turned into a left-wing city. Somewhere from the $8^{\text {th }}$ to the $15^{\text {th }}$ kilometre we can talk about a left-wing Prague. This is what I have called the 'left-wing orb' above (see the description of Figure 4). However, from 15 kilometres there are mixed territories that tended to vote for the right.

The scatterplot for Warsaw, similarly to the map, does not show any positive or negative link between the distance and factor score, representing a tendency of voters towards one or the other side of spatial electoral polarisation. The fit line indicates only a very slight downward trend.

\section{Discussion and conclusions}

Prague and Warsaw are among the largest metropolises in Central Europe. The cities are similar in many ways, but different in one important aspect: Warsaw was completely destroyed during World War II. However, the city was rebuilt just after the war, thanks to extensive investment and the enormous enthusiasm for construction of the Polish people. Within a few years, it grew pretty much to its original size.

And yet, the renewed Warsaw was no longer the city it had been. It lacked much of the population, lost its genius loci or spirit, and most importantly, the long-standing social conflict between the various social classes - which Burgess (1925) describes in his sociological model of the city - was interrupted. The flat-out destruction of the city might mean that its social structure - that had previously been formed and organised for decades and centuries - suddenly did not exist anymore. The so-called social conflict over territory thus began from the beginning, or nearly from the beginning, certain people's relations with the land probably continued to exist. Undoubtedly, rebuilding a city means creating a new spatial social structure. This is not what Prague has gone through. A significant interference with the natural social development of the city, however, did occur during the period of radical communist construction.

The point of this article is not to discuss historical events, though these did serve as the basis for the selection of the cases examined. Of course, I do not want to hide that my selection of cases was also done by my understanding of the Polish and Czech languages and access to data. However, the choice of these two cities gives the article a particularly comparative dimension.

The paper is neither entirely qualitative nor quantitative. Nor is it entirely comparative. Its purpose is to contribute to the conceptual and theoretical discussion of urban electoral geography, which is still at an early stage. Urban electoral geography has so far been satisfied with descriptive and correlation 
research only and little or no consideration has been given to a deeper theoretical explanation behind it. In this paper, I suggest the Burgess sociological model of the city as a theoretical explanatory framework. Nevertheless, the selection of the model was not intuitive. In earlier exploratory study Kerekes (2018a) demonstrated which variables can best to explain spatial variation in Prague. The exploration showed that the best explanatory variable is distance from the centre. Within certain limits, Burgess's model of concentric zones can be operationalised using the distance from the centre.

In this study, I processed the electoral data at the ward level and transferred it into space - into a map. In the case of Warsaw, this was a challenging process, and it needed a great deal of manual data processing. The analysis showed that Prague's electoral behaviour had the characteristics of a zonal arrangement. The arrangement was in fact very similar to that of the Burgess city model. It can be seen that in the centre in Prague the electorate was strongly in favour of right-wing parties. This would correspond to the concept of Central Business District as described by Burgess (1925). Then the surrounding left-leaning territories could represent the Transition Zone and the Working Class Zone. In Burgess's model these territories are poor and occupied by the working class. This explains their affection for the left. Finally, there was a tendency towards a right-wing vote in the outermost parts. It could just be the outer suburbs, the so-called White Collar Zone and Commuter Zone, where economically stronger inhabitants live and therefore prefer the rightwing parties. That is why I have used the onion metaphor in the title of the article, as the onion, with its layered structure, has a concentric arrangement.

On the other hand, Warsaw did not show such a structure. This might be attributed to several factors. One explanation that I am inclined to endorse is that the WWII destruction of the city had erased the city's concentric structure. This could support my original argument, namely that the sociological theory of the city can be used as a theoretical framework for an explanation of the electoral geography of cities. The very opposing explanation is that there was no concentric organisation of electoral behaviour in the city and that the case of Prague is just a coincidence. However, this is not supported by the many studies noted in the literature review that have described the dichotomy between the city centre and its surroundings.

I suggest that further electoral geography research, following the findings of this article, does not focus necessarily only on testing the Burgess model, but also on developing it further, conceptually and methodologically; alternatively, to adapt the model to the conditions of electoral geography.

Finally, I want to return to the issue of visualisation. The by-products of this article include two maps. Data visualisation is important, and often indispensable, in every piece of quantitative research, and I think this is all the 
more valid for electoral geography. Visualising spatial data is not always easy, especially with a big $N$ and in an effort to keep the visualisation clear and understandable. In this respect, I want to make this article innovative. On the one hand, I chose to visualise only one variable for each city, instead of visualising the support for each party on separate maps. The reasoning behind this was to provide a more holistic view of the cases under study. On the other hand, I decided to replace the visualisation of ward electoral data in polygons, as is usual in electoral geography, by visualising in points. Visualisation in polygons is often distorted, because the size of the polygon is dependent on some third variable (the size of administrative territory), which is a problem in big cities. As a rule, large polygons represent little populated and sparsely built-up areas, while small polygons are small but densely populated areas. This then conduces the reader towards the interpretation that large polygons have a greater weight in the map. I have tried to overcome this by visualising with the help of address points. The problem, of course, is not eliminated completely, but it is significantly mitigated. Therefore, in further electoral geography research, I suggest that urban electoral data is visualised using address points, by transferring data from polygons to points.

In conclusion, I would like to encourage political scientists, sociologists and geographers to research cities in terms of electoral geography. For a long time, electoral geography has seemed to stagnate and not contribute any new knowledge. However, it is precisely the increasing availability of data that allows more detailed research on urban phenomena. The city is an entity full of various sociological phenomena, and many of them are pathological - yet we do not qualitatively examine them. Often, the absence of good sociological data serves as an excuse. The city is like an anthill. Anthills can be counted in a field. We know that inside the anthill there is a lively life with interesting phenomena, but we do not quantify and describe them with the help of data. However, as noted by O'Louglin et al. (1997) and Charney and Malkinson (2015), electoral data continue to provide an up-to-date and inexpensive alternative to missing sociological data.

Daniel Kerekes just recently received PhD in Political Science at Masaryk University. His research and lecturing interest lies in the fields of electoral geography, electoral systems, and electoral law. Besides academia, he works as a political consultant and participates in electoral observation missions.

\section{REFERENCES}

ABBOTT, W., 1974: Moscow in 1897 as a Preindustrial City: A Test of the Inverse Burgess Zonal Hypothesis. American Sociological Review 39(4), pp. 542-550.

ARCHER, J. C. - SHELLEY, F. M., 1985: Theory and Methodology in Political Geography. In: Pacione, M. (eds.): Progress in political geography. New York: Routledge, pp. 11-40. 
BAHNA, M. - KEREKES, D. - MAJO, J., 2018: Vol'by 2016 v Bratislave a v Košiciach: ako volia vel'ké slovenské mestá. In: Krivý, V. (eds.): Slovenské vol'by 2016: retrospektívne analýzy. Bratislava: Slovak Academy of Sciences, pp. 142-172.

BAHNA, M. - MAJO, J., 2012: Bratislava zblízka. Vol'by '12 a '10. In: Krivý, V. (ed.): Slovenské vol'by '12: čo im predcházalo, postoje a výsledky. Bratislava: Slovak Academy of Sciences, pp. 203-235.

BALAKRISHNAN, T. R. - JARVIS, G., 1991: Is the Burgess Concentric zonal theory of spatial differentiation still applicable to urban Canada? Canadian Review of Sociology 28(4), pp. 526-539.

BERELSON, B. - LAZARSFELD, P. F. - McPHEE, W. N., 1954: Voting: A study of Opinion Formation in a Presidential Campaign. Chicago: University of Chicago Press 395 p.

BEYNON, E., 1943: Budapest: An Ecological Study. Geographical Review 33(2), pp. 256-275.

BORISYUK, G. - RALLINGS, C. - THRASHER, M. - KOLK, H., 2007: Voter Support for Minor Parties: Assessing the Social and Political Context of Voting at the 2004 European Elections in Greater London. Party Politics 13(6), pp. 669-693.

BROWN, M. - KNOPP, L. - MORRILL, R., 2005: The Culture Wars and Urban Electoral Politics: Sexuality, Race, and Class in Tacoma, Washington. Political Geography 24(3), pp. 267-291.

BURGESS, E., 1925. The Growth of the City: An Introduction to a Research Project. In: Park, R., - Burgess, E. - McKenzie, R.: The city. Chicago: University of Chicago Press, pp. 47-62.

CASTLE, I. M. - GITTUS, E., 1957: The Distribution of Social Defects in Liverpool. The Sociological Review 5(1), pp. 43-64.

COLLISON, P. - MOGEY, J., 1959: Residence and Social Class in Oxford. American Journal of Sociology 64(6), pp. 599-605.

COX, K. R., 1968: Suburbia and Voting Behavior in the London Metropolitan Area. Annals of the Association of American Geographers 58(1), pp. 111-127.

ČTYROKÝ, J., 2017: Kde má Praha centrum? In: Konference GIS Esri v ČR [online]. Př́ispěvek na konferenci. Praha. 11.8. [cit. 1. júl 2018]. Dostupné na: http://download.arcdata.cz/konf/2017/prednasky/prezentace-PDF/P_Ctyroky_IPR.pdf

DE MAESSCHALCK, F., 2011: The Politicisation of Suburbanisation in Belgium: Towards an Urban-Suburban Divide. Urban Studies 48(4), pp. 699-717.

DEAR, M., 2001: The Postmodern Urban Condition. Oxford: Wiley-Blackwell, 352 p.

DEAR, M., 2003: The Los Angeles School of Urbanism: An Intellectual History. Urban Geography 24(6), pp. 493-509.

FLINT, C. - TAYLOR, P. J., 2007: Political Geography: World-Economy, Nation-State and Locality. New York: Routledge, $340 \mathrm{p}$.

GAINSBOROUGH, J. F., 2001: Fenced off: The Suburbanization of American Politics. Washington: Georgetown University Press, $191 \mathrm{p}$.

GAINSBOROUGH, J. F., 2005: Voters in Context: Cities, Suburbs, and Presidential Vote. American Politics Research 33(3), pp. 435-461.

GOSNELL, H. F. - SCHMIDT, M. J., 1936: Factorial and Correlational Analysis of the 1934 Vote in Chicago. Journal of the American Statistical Association 31(195), pp. 507-518.

GREENSTEIN, F. I. - WOLFINGER, R. E., 1958: The Suburbs and Shifting Party Loyalties. The Public Opinion Quarterly 22(4), pp. 473-482.

GUTOIU, G., 2018: Electoral Geography and the Post-Socialist City: Is the Pre-World War II Urban Tissue Still Important? Evidence from Bucharest at the Romanian parliamentary elections of 2016. European Quarterly of Political Attitudes and Mentalities 7(3), pp. 47-60.

HARRIS, L., 1954. Is there a Republican Majority? Political Trends, 1952 - 1956. New York: Harper. 
HARRIS, Ch. - ULLMAN, E. 1945: The Nature of Cities. The Annals of the American Academy of Political and Social Science 242(1), pp. 7-17.

HAUSER, F., 1951: The Ecological Pattern of Four European Cities and Two Theories of Urban Expansion. Journal of the American Institute of Planners 17(3), pp. 111-129.

HOYT, H., 1939: The Structure and Growth of Residential Neighborhoods in American Cities. Washington: U.S. Government Printing Office. 204 p.

CHARNEY, I. - MALKINSON, D., 2015: Between Electoral and Urban Geography: Voting Patterns and Socio-Spatial Dynamics in Tel Aviv. Applied Geography 58(Supplement C), pp. 1-6.

IGNÁCZ, K., 2013. Budapest választ: parlamenti és törvényhatósági választások a fővárosban 1920 - 1945. Budapest: Napvilág Kiadó, 198 p.

JANOSIK, G. E., 1956: The New Suburbia. Current History 31(180), pp. 91-95.

KASPERSON, R. E., 1965: Toward a Geography of Urban Politics: Chicago, a Case Study. Economic Geography 41(2), pp. 95-107.

KATZ, E. - LAZARSFELD, P. F., 1955. Personal Influence: The Part Played by People in the Flow of Mass Communication. New York: Free Press, 400 p.

KEREKES, D., 2018a: Ako skúmat' vol'by v priestore mesta: prípad snemovných volieb 2017 v Prahe. Central European Political Studies Review 20(2), pp. 147-181.

KEREKES, D., 2018b: Vol’by 2016 v Košiciach: priestorová analýza. Sociológia 50(1), pp. $31-$ 56.

KOSTELECKÝ, T. - MIKEŠOVÁ, R. - POLÁKOVÁ, M. - ČERMÁK, D. - BERNARD, J. ŠIMON, M., 2014: Koho volí Vaši sousedé? Prostorové vzorce volebního chování na území Česka od roku 1920 do roku 2006, jejich změny a možné příčiny. Praha: Sociologický ústav AV ČR, 173 p.

KOSTELECKÝ, T. - MIKEŠOVÁ, R. - POLÁKOVÁ, M. - ČERMÁK, D. - BERNARD, J. ŠIMON, M., 2015: Geografie výsledků parlamentních voleb: vzorce volebního chování v Česku 1992 - 2013. Praha: Sociologický ústav AV ČR, 209 p.

LAZARSFELD, P. F. - BERELSON, B. - GAUDET, H., 1944: The People's Choice: How the Voter Makes up his Mind in a Presidential Campaign. New York: Duell, Sloan and Pearce, $196 \mathrm{p}$.

LAZERWITZ, B., 1960: Suburban Voting Trends: 1948 to 1956. Social Forces 39(1), pp. 29-36.

LEIB, J. - QUINTON, N., 2011: On the Shores of the "Moribund Backwater"? Trends in Electoral Geography Research Since 1990. In: Warf, B. - Leib, J. (eds.): Revitalizing electoral geography. Burlington: Ashgate, pp. 9-30.

LEWIS, P. F., 1965: Impact of Negro Migration on the Electoral Geography of Flint, Michigan, 1932 - 1962: A Cartographic Analysis. Annals of the Association of American Geographers 55(1), pp 1-25.

LIPSET, S. M. - ROKKAN, S., 1967: Party Systems and Voter Alignments: Cross-National Perspectives. New York: Free Press, 554 p.

McELRATH, D., 1962: The Social Areas of Rome: A Comparative Analysis. American Sociological Review 27(3), pp. 376-391.

MEYER, W. - ESPOSITO, CH., 2015: Burgess and Hoyt in Los Angeles: Testing the Chicago Models in an Automotive-Age American City. Urban Geography 36(2), pp. 314-325.

MINGHI, J. V. - RUMLEY, D., 1978: Toward a Geography of Campaigning: some Evidence from a Provincial Election in Vancouver, British Columbia. Canadian Geographer 22(2), pp. 145-162.

MOSCHELES, J., 1937: The Demographic, Social, and Economic Regions of Greater Prague: A Contribution to Urban Geography. Geographical Review 27(3), pp. 414-429.

NATHAN, N. L., 2016: Local Ethnic Geography, Expectations of Favoritism, and Voting in Urban Ghana. Comparative Political Studies 49(14), pp. 1896-1929. 
O'LOUGHLIN, J. - KOLOSSOV, V. - VENDINA, O., 1997: The Electoral Geographies of a Polarizing City: Moscow, 1993 - 1996. Post-Soviet Geography and Economics 38(10), pp. 567-600.

OUŘEDNÍČEK, M. - POSPISILOVA, L. - ŠPAČKOVÁ, P. - TEMELOVÁ, J. - NOVÁK, J., 2012: Prostorová typologie a zonace Prahy. In: Ouředníček, M. - Novák, J. (eds.): Sociální proměny pražských čtvrtí. Praha: Academia, pp. 268-297.

PINK, M., 2018: Teritoriální homogenita a heteriogenita českých senátních voleb 1996 - 2016. Brno: Centrum pro studium demokracie a kultury. 223 p.

PLEŠIVČÁK, M., 2013: Politický život Bratislavy z perspektívy jej volebného správania. In: Buček, J. - Korec, P. (eds.): Moderná humánna geografia mesta Bratislava: priestorové štruktúry, siete a procesy. Bratislava: Comenius University, pp. 257-312.

REYNOLDS, D. R., 1990: Whither Electoral Geography? A Critique. In: Johnston R. - Shelley, F. M. - Taylor, P. J. (eds.): Developments in Electoral Geography. First edition. London: Routledge, pp. 22-34.

RUMLEY, D. - MINGHI, J., 1977: A Geographic Framework for the Study of the Stability and Change of Urban Electoral Patterns. Tijdschrift voor economische en sociale geografie 68(3), pp. 177-182.

SALTER, P. S. - MINGS, R. C., 1972: The Projected Impact of Cuban Settlement on Voting Patterns in Metropolitan Miami, Florida. The Professional Geographer 24(2),pp. 123-131.

SHEARMUR, R. - CHARRON, M., 2004: From Chicago to L.A. and Back Again: A ChicagoInspired Quantitative Analysis of Income Distribution in Montreal. The Professional Geographer 56(1), pp. 109-126.

SONENSHEIN, R. J. - DRAYSE, M. H., 2006: Urban Electoral Coalitions in an Age of Immigration: Time and Place in the 2001 and 2005 Los Angeles Mayoral Primaries. Political Geography 25(5), pp. 570-595.

ŠIMON, M., 2015: Measuring Phantom Borders: The Case of Czech/Czechoslovakian Electoral Geography. Erdkunde 69(2), pp. 139-150.

ŠUŠKA, P. - ŠVEDA, M. - KRIVÝ, V., 2018: Hodnotová zmena v zázemí Bratislavy ako dôsledok suburbánneho rozvoja: analýza volebného správania. Sociológia 50(5), pp. 609631. https://doi.org/10.31577/sociologia.2018.50.5.23

ŠUŠKA, P. - ك̌VEDA, M. - VÝBOŠŤOK, J., 2019: Suburbiá napravo? Zmena volebného správania ako dôsledok suburbánneho rozvoja. In: Šveda, M. - Šuška P. (eds.): Suburbanizácia: ako sa mení zázemie Bratislavy? Bratislava: Geografický ústav SAV, pp. 163-180.

WALKS, R. A., 2004: Place of Residence, Party Preferences, and Political Attitudes in Canadian Cities and Suburbs. Journal of Urban Affairs 26(3), pp. 269-295.

WALKS, R. A., 2005: City-Suburban Electoral Polarization in Great Britain, 1950 - 2001. Transactions of the Institute of British Geographers 30(4), pp. 500-517.

WALKS, R. A., 2006: The Causes of City-Suburban Political Polarization? A Canadian Case Study. Annals of the Association of American Geographers 96(2), pp. 390-414.

WEBSTER, G. R. - WEBSTER, R. H., 1987: Ethnicity and Voting in the Miami-Dade County SMSA. Urban Geography 8(1), pp. 14-30.

WĘCŁAWOWICZ, G. - JAROSZ, A. - ŚLESZYŃSKI, P. 1998: Wybory parlamentarne 1991 i 1993. In: Węcławowicz, G. - Księżak, J. - Jarosz, A. - Śleszyński, P. (eds.): Atlas Warszawy. Wasrsaw: IGiPZ PAN, pp. 7-90.

WHYTE, W., 1956: The Organization Man. New York: Simon and Schuster, 448 p.

WILLIAM-OLSSON, W., 1940: Stockholm: Its Structure and Development. Geographical Review 30(3), pp 420-438. 